\title{
HUBUNGAN KADAR KOLESTEROL TOTAL DAN HIPERTENSI PADA ORANG YANG MELAKUKAN OLAHRAGA SENAM JANTUNG SEHAT DI KECAMATAN GLUMPANG TIGA
}

\author{
Zuraida $^{1}$, Aditya Candra², Abdul Wahab² \\ ${ }^{1}$ Program Studi Kedokteran, Fakultas Kedokteran, Universitas Abulyatama \\ ${ }^{2}$ Dosen Program Studi Pendidikan Dokter, Fakultas Kedokteran, Universitas \\ Abulyatama
}

[Email korespondensi: zuraidaraida73@gmail.com]

\begin{abstract}
Relationship of Total Cholesterol Levels and Hypertension in People Doing Healthy Heart Exercise in Glumpang Tiga District. The health problem that is in the spotlight now is the increase in sufferers of cardiovascular disease. Risk factors for cardiovascular disease include cholesterol and hypertension. Sport is a series of regular and planned physical exercises to maintain movement and improve movement ability. This study aims to look at the relationship of total cholesterol levels and hypertension in people who exercise in Glumpang Tiga District. This type of research is a descriptive analytic study with a cross sectional study design. The sampling technique in this study is simple random sampling. The number of samples 55 people consisting of 28 cholesterol respondents and 27 hypertensive respondents. Data analysis uses chi-square test. The results of the study are that there is no relationship between sex and age on total cholesterol levels with their respective $p$-values namely $P=0.361$ and $P=$ 0.110 and there is no relationship between sex and age on hypertension with their respective $p$-values namely $P=0.785$ and $P=0.321$. There is a relationship between exercise with total cholesterol and hypertension with $\mathrm{P}<0.05$.
\end{abstract}

Keywords: Healthy Heart Exercise, Total Cholesterol, Hypertension.

Abstrak:Hubungan Kadar Kolesterol Total dan Hipertensi pada Orang yang Melakukan Olahraga Senam Jantung Sehat Di Kecamatan Glumpang Tiga. Masalah kesehatan yang menjadi sorotan saat ini adalah meningkatnya penderita penyakit kardiovaskular. Faktor resiko penyakit kardiovaskular antara lain kolesterol dan hipertensi. Olahraga adalah serangkaian gerak raga yang teratur dan terencana untuk memelihara gerak dan meningkatkan kemampuan gerak. Penelitian ini bertujuan untuk melihat hubungan kadar kolesterol total dan hipertensi pada orang yang melakukan olahraga di Kecamatan Glumpang Tiga. Jenis penelitian ini adalah penelitianDeskriptif Analitik dengan desain penelitian Cross Sectional Study(studi potong lintang).Teknik pengambilan sampel dalam penelitian ini adalah teknik acak sederhana (simple random sampling).Jumlah sampel 55 orang yang terdiri dari 28 orang responden kolesterol dan 27 orang responden hipertensi.Analisa data menggunakan uji chi-square test. Hasil penelitian yaitu tidak terdapat hubungan antara jenis kelamin dan usia terhadap kadar kolesterol total dengan $p$-value masing-masing yaitu $P=0,361$ dan $P=0,110$ serta tidak terdapat hubungan antara jenis kelamin dan usia terhadap hipertensi dengan $\mathrm{p}$-value masing-masing yaitu $\mathrm{P}=0,785$ dan $\mathrm{P}=0,321$. Terdapat hubungan antara olahraga dengan kadar kolesterol total dan hipertensi dengan $\mathrm{P}<0,05$.

Kata Kunci:Olahraga Senam Jantung Sehat, Kolesterol Total, Hipertensi. 


\section{PENDAHULUAN}

Masalah kesehatan di Indonesia
saat ini menjadi gambaran permasalahan yang sangat rumit dan terus berkembang serta belum ada akhirnya. Masalah kesehatan yang menjadi sorotan saat ini adalah meningkatnya penderita penyakit kardiovaskular(Wahyuni, 2014). Penyakit kardiovaskular masih menjadi ancaman dunia (global threat) dan merupakan penyakit yang berperan utama sebagai penyebab kematian nomor satu di seluruh dunia (PERKI, 2019). Faktor resiko penyakit kardiovaskular terdiri dari faktor resiko yang tidak dapat dimodifikasi: riwayat keluarga, umur, jenis kelamin, obesitas serta yang dapat dimodifikasi: hipertensi, dislipidemia, diabetes mellitus, kurang aktivitas fisik, diet tidak sehat, serta stress. Penyakit kardiovaskular adalah penyakit yang disebabkan gangguan fungsi jantung dan pembuluh darah, seperti: penyakit jantung koroner (PJK), gagal jantung, hipertensi dan stroke (Kementerian Kesehatan RI, 2018).

Kolesterol merupakan salah satu komponen lemak atau zat lipid yang sangat diperlukan oleh tubuh kita selain zat gizi lainnya, seperti karbohidrat, protein, vitamin dan mineral (Naim et al, 2019). Lipid adalah substansi lemak, agar dapat larut dalam darah, molekul lipid harus terikat pada molekul protein (yang dikenal dengan nama apolipoprotein, yang sering disingkat dengan nama apo. Senyawa lipid dengan apolipoprotein yang terkandung maka dikenal lima jenis apolipoprotein yaitu kilomikron, very low-density lipoprotein (VLDL), intermediate density lipo protein (VLDL), intermediate density lipo protein (IDL), low-density lipoprotein (LDL), dan high density lipoprotein ( $\mathrm{HDL}$ ). Kelainan fraksi lipid yang utama adalah kenaikan kadar kolesterol total, kolesterol LDL, dan atau trigliserid (TG), serta penurunan kolesterol HDL (Arsana et al, 2019). Kelebihan kolesterol dalam pembuluh darah dapat menyebabkan penyempitan dan pengerasan yang disebut aterosklerosis (Magdalena, 2015).
Menurut World Health Organization (WHO)2014, penyakit kardiovaskular merupakan pembunuh nomor satu di dunia dan diperkirakan 12 juta orang meninggal tiap tahunnya (Putriastuti, 2016). Abnormalitas lipid plasma berperan utama dalam patogenesis terjadinya aterosklerosis pada dinding pembuluh darah yang merupakan penyebab terjadinya penyakit jantung koroner (PJK) dan stroke (Lin et al, 2018; Arsana et al, 2019). Kedua penyakit tersebut merupakan penyebab kematian utama didunia yaitu mencapai 17,3 juta dari 54 juta total kematian pertahun (WHO, 2014; Benjamin et al, 2017). Dari jumlah total penderita stroke di Indonesia, sekitar 2,5 persen atau 250 ribu orang meninggal dunia dan sisanya cacat ringan maupun berat. Pada 2020 mendatang diperkirakan 7,6 juta orang akan meninggal karena stroke (Badan Penelitian dan Pengembangan Kesehatan Kementrian Kesehatan RI, 2014).

Hipertensi adalah suatu keadaan dimana terjadi peningkatan tekanan darah sistolik lebih atau sama dengan $140 \mathrm{mmHg}$ dan atau tekanan darah diastolik lebih atau sama dengan 90 $\mathrm{mmHg}$ (Kemenkes RI, 2016). Hipertensi sangat dipengaruhi oleh gaya hidup yang tidak sehat (Hafid, 2015). Secara global, hipertensi diperkirakan menyebabkan 7,5 juta kematian. Prevalensi hipertensi tertinggi berada di Afrika yaitu sebesar $46 \%$ pada laki-laki dan perempuan. Di Inggris, 34\% lakilaki dan $30 \%$ perempuan menderita hipertensi atau sedang mendapatkan pengobatan hipertensi. Prevalensi hipertensi di dunia hampir satu miliar orang dan diperkirakan pada tahun 2025, jumlahnya mencapai 1,6 miliar orang(Putriastuti, 2016). Berdasarkan sistem informasi surveilans PTM (Penyakit Tidak Menular) berbasis web di Indonesia, jumlah orang yang diagnosis hipertensi menurut kelompok umur di puskesmas tahun 2016 terbanyak pada kelompok produktif (umur 35-59 tahun) sebesar 73.639 (Kemenkes RI, 2016).

Olahraga merupakan salah satu cara untuk meningkatkan ketahanan 
fisik juga sebagai upaya memelihara kesehatan dan kebugaran. Latihan fisik merupakan salah satu upaya untuk mengatasi kelebihan lemak sekaligus untuk mencapai tingkat kesegaran jasmani yang baik.Intensitas olahraga juga berpengaruh dalam perubahan profil lipid darah. Semakin besar intensitas olahraga yang dilakukan, kemungkinan untuk menurunkan kadar kolesterol semakin besar, sehingga resiko terjadinya penyakit jantung koroner akan berkurang (Harimba, 2017). Di Indonesia salah satu jenis olahraga yang terkenal adalah senam jantung sehat. Senam jantung sehat adalah olahraga yang disusun dengan selalu mengutamakan kemampuan jantung, gerakan otot besar dan kelenturan sendi, serta upaya memasukkan oksigen sebanyak mungkin (Ayu et al, 2017).

Olahraga yang teratur merangsang penurunan kadar hepatic trigliserida lipase dan cholesterol ester transfer protein (CETP) yang berakibat pada peningkatan kadar HDL (High Density Lipoprotein), selain itu terjadi peningkatan enzim lipoprotein lipase yang membantu LDL (Low Density Lipoprotein) di pembuluh darah bergerak menuju hati (Ayu et al, 2017). Olahraga secara teratur terbukti dapat meningkatkan fungsi kardiovaskular serta meperbaiki fungsi tubuh (Putriastuti, 2016). Latihan olahraga dapat menurunkan tekanan sistolik maupun diastolik pada usia tengah baya (35-50 tahun), yang sehat, dan juga mereka yang mempunyai tekanan darah tinggi ringan (Munawarah, 2017).

Di Aceh, beberapa waktu terakhir telah digalakkan berolahraga untuk meningkatkan kebugaran jasmani dan rohani. Kegiatan olahraga telah banyak dilakukan mulai dari desa sampai kota.Terdapat banyak institusi yang juga ikut menyelenggarakan kegiatan olahraga bersama, salah satunya senam rutin setiap minggu di puskesmas. Mengetahui bahwa kadar kolesterol yang abnormal dan hipertensi merupakan salah satu penyebab terjadinya berbagai penyakit antara lain penyakit jantung koroner (PJK) dan stroke. Keadaan ini dapat dicegah dengan melakukan olahraga atau aktivitas fisik.Berdasarkan latar belakang diatas, peneliti tertarik untuk mengetahui Hubungan Kadar Kolesterol Total dan Hipertensi pada Orang yang Melakukan Olahraga Senam Jantung Sehat Di Kecamatan Glumpang Tiga.

\section{METODE}

Penelitian ini merupakan penelitian Deskriptif Analitik dengan desain penelitian Cross Sectional Study.Pengambilan data dari data primer dan sekunderdengan teknik pengumpulan data responden melalui aplikasi google form. Jumlah sampel yang digunakan 55 orang yang terdiri dari 28 orang sampel koleterol dan 27 orang sampel hipertensi.

\section{HASIL}

\section{A. Analisa Univariat}

Tabel 1.Distribusi Frekuensi Berdasarkan Jenis Kelamin, Usia, Olahraga, dan Kadar Kolesterol Pada Responden Kadar Kolesterol Total

\begin{tabular}{lcc}
\hline Kelompok & Frekuensi (n) & Persentase (\%) \\
\hline Jenis Kelamin & & \\
\hline Laki-Laki & 5 & 17,9 \\
Perempuan & 23 & 82,1 \\
\hline Total & 28 & $100 \%$ \\
\hline Usia & & \\
\hline 31- 40 Tahun & 2 & 7,1 \\
51 - 60 Tahun & 7 & 25,2 \\
61 - 65 Tahun & 11 & 39,3 \\
\hline
\end{tabular}




\begin{tabular}{lcc}
\hline Total & 28 & $100 \%$ \\
\hline Olahraga & & \\
\hline Sering & 19 & 67,9 \\
Jarang & 9 & 32,1 \\
\hline Total & 28 & $100 \%$ \\
\hline Kolesterol & & \\
\hline Normal & 15 & 53,6 \\
Resiko Sedang & 8 & 28,6 \\
Resiko Tinggi & 5 & 17,8 \\
\hline Total & 28 & $100 \%$ \\
\hline
\end{tabular}

Berdasarkan Tabel 1,responden kadar kolesterol total dengan jenis kelamin lakilaki yaitu sebanyak 5 responden $(17,9 \%)$ dan jenis kelamin perempuan yaitu sebanyak 23 responden (82,1\%). Responden kadar kolesterol total dengan usia 31-40 yaitu sebanyak 2 responden $(7,1 \%)$, usia $41-50$ tahun yaitu sebanyak 7 responden $(25,2 \%)$, usia $51-60$ tahun yaitu sebanyak 11 responden $(39,3 \%)$, dan usia 61-65 tahun yaitu sebanyak 6 responden $(21,4 \%)$. Responden kadar kolesterol total yang sering olahraga yaitu sebanyak 19 responden (67,9\%) dan responden yang jarang olahraga yaitu sebanyak 9 responden (32,1\%).Rata-rata kadar kolesterol total responden adalah sebesar 204,46mg/dl (Resiko Sedang), dengan kadar kolesterol total minimum sebesar $170 \mathrm{mg} / \mathrm{dl}$ (Normal) dan kadar kolesterol total maksimum sebesar 270 $\mathrm{mg} / \mathrm{dl}$ (Resiko Tinggi). Responden dengan kadar kolesterol total kelompok normal yaitu sebanyak 15 responden $(53,6 \%)$, responden dengan kadar kolesterol total kelompok resiko sedang yaitu sebanyak 8 responden $(28,6 \%)$, dan responden dengan kadar kolesterol total kelompok resiko tinggi yaitu sebanyak 5 responden $(17,8 \%)$.

Tabel 2.Distribusi Frekuensi Berdasarkan Jenis Kelamin, Usia, Olahraga, dan Kadar Kolesterol Pada Responden Hipertensi

\begin{tabular}{lcc}
\hline Kelompok & Frekuensi (n) & Persentase (\%) \\
\hline Jenis Kelamin & 9 & \\
\hline Laki-Laki & 18 & 33,3 \\
Perempuan & 27 & 66,7 \\
\hline Total & & $100 \%$ \\
\hline Usia & 3 & \\
\hline $31-40$ Tahun & 5 & 11,1 \\
$41-50$ Tahun & 10 & 18,5 \\
$51-60$ Tahun & 9 & 37 \\
$61-65$ Tahun & 27 & 33,4 \\
\hline Total & & $100 \%$ \\
\hline Olahraga & 18 & \\
\hline Sering & 9 & 66,7 \\
Jarang & 27 & 33,3 \\
\hline Total & & $100 \%$ \\
\hline Nipertensi & 14 & \\
Hipertensi & 13 & 51,9 \\
\hline Total & 27 & 48,1 \\
\hline
\end{tabular}

Tabel 2 menunjukkan, responden hipertensi dengan jenis kelamin laki-laki yaitu 9 responden $(33,3 \%)$ dan jenis kelamin perempuan sebanyak 18 responden $\quad(66,7 \%)$. Responden hipertensi dengan usia 32-40 tahun yaitu 3 responden $(11,1 \%)$, usia $41-50$ tahun yaitu 5 responden $(18,5 \%)$, usia 51-60 tahun sebanyak 10 responden (37\%) dan usia 61-65 tahun sebanyak 9 responden (33,4\%). Responden hipertensi yang sering olahraga 18 
responden $(66,7 \%)$ dan responden yang jarang olahraga 9 responden $(33,3 \%)$. Rata-rata nilai sistol responden adalah sebesar 130,37 mmHG (normal) dan untuk rata-rata nilai diastol responden adalah sebesar 82,04 mmHG (normal).
Responden yang tekanan darah normal yaitu sebanyak 14 responden (51,9\%) dan responden yang hipertensi yaitu13 responden $(48,1 \%)$.

\section{B. Analisa Bivariat}

Tabel 3. HubunganJenis Kelamin, Usia, Olahraga, terhadap Kadar Kolesterol Kadar Kolesterol

\begin{tabular}{|c|c|c|c|c|c|c|c|c|c|}
\hline \multirow[t]{2}{*}{ Kelompok } & \multicolumn{2}{|c|}{ Normal } & \multicolumn{2}{|c|}{$\begin{array}{l}\text { Resiko } \\
\text { Sedang }\end{array}$} & \multicolumn{2}{|c|}{$\begin{array}{l}\text { Resiko } \\
\text { Tinggi }\end{array}$} & \multicolumn{2}{|c|}{ Jumlah } & \multirow[t]{2}{*}{$\mathbf{P}$} \\
\hline & $\mathbf{F}$ & $\%$ & $\mathbf{F}$ & $\%$ & $\mathbf{F}$ & $\%$ & $\mathbf{F}$ & $\%$ & \\
\hline \multicolumn{9}{|c|}{ Jenis Kelamin } & \multirow{4}{*}{0,361} \\
\hline Laki-Laki & 2 & 40,0 & 1 & 20,0 & 2 & 40,0 & 5 & 100,0 & \\
\hline Perempuan & 13 & 56,5 & 7 & 30,4 & 3 & 13,0 & 23 & 100,0 & \\
\hline Total & 15 & 53,6 & 8 & 28,6 & 5 & 17,9 & 28 & 100,0 & \\
\hline \multicolumn{9}{|l|}{ Usia } & \\
\hline $31-40$ & 0 & 0,0 & 2 & 100,0 & 0 & 0,0 & 2 & 100,0 & \multirow{5}{*}{0,110} \\
\hline $41-50$ & 3 & 33,3 & 3 & 33,3 & 3 & 33,3 & 9 & 100,0 & \\
\hline $51-60$ & 7 & 63,6 & 3 & 27,3 & 1 & 9,1 & 11 & 100,0 & \\
\hline $61-70$ & 5 & 83,3 & 0 & 0,0 & 1 & 16,7 & 6 & 100,0 & \\
\hline Total & 15 & 53,6 & 8 & 28,6 & 5 & 17,9 & 28 & 100,0 & \\
\hline \multicolumn{9}{|l|}{ Olahraga } & \\
\hline Sering & 15 & 78,9 & 4 & 21,1 & 0 & 0,0 & 19 & 100,0 & \multirow{3}{*}{0,000} \\
\hline Jarang & 0 & 0,0 & 4 & 44,4 & 5 & 55,6 & 9 & 100,0 & \\
\hline Total & 15 & 53,6 & 8 & 28,6 & 5 & 17,9 & 28 & 100,0 & \\
\hline
\end{tabular}

Berdasarkan Tabel 3, jenis kelamin laki-laki lebih banyak responden dengan kolesterol normal dan resiko tinggi yaitu 2 orang $(40,0 \%)$. Sedangkan untuk jenis kelamin perempuan lebih banyak responden dengan kolesterol normal yaitu 13 orang $(56,5 \%)$. Untuk mengetahui hubungan antara jenis kelamin dengan kadar kolesterol total dilakukan tabulasi silang (analisis chisquare) dan secara statistik menunjukkan tidak terdapat hubungan antarajenis kelamin dengan kadar kolesterol total, dengan nilai $P=0,361$ ( $P$ $>0,05$ ). Hubungan antara usia dengan kadar kolesterol total dilakukan tabulasi silang (analisis chi-square) dan secara statistik menunjukkan tidak terdapat hubungan antarausia dengan kadar kolesterol total, dengan nilai $P=0,110$ ( $P$ $>0,05$ ).

Responden yang sering olahraga lebih banyak berada pada kelompok kolesterol normal yaitu sebesar 15 orang $(78,9)$. Sebaliknya, untuk responden yang jarang olahraga lebih banyak berada pada kelompok kolesterol resiko tinggi yaitu sebesar 5 orang $(55,6 \%)$. Secara statistik menunjukkanterdapat hubungan antaraolahraga dengan kadar kolesterol total, dengan nilai $P=0,000(P<0,05)$.

Tabel 4. HubunganJenis Kelamin, Usia, Olahraga, terhadap Hipertensi

\begin{tabular}{|c|c|c|c|c|c|c|c|}
\hline \multirow{3}{*}{ Kelompok } & \multicolumn{4}{|c|}{ Hipertensi } & \multicolumn{2}{|c|}{ Jumlah } & \multirow{2}{*}{$\mathbf{P}$} \\
\hline & \multicolumn{2}{|c|}{ Normal } & \multicolumn{2}{|c|}{ Hipertensi } & \multirow[b]{2}{*}{$\mathbf{F}$} & \multirow[b]{2}{*}{$\%$} & \\
\hline & $\mathbf{F}$ & $\%$ & $\mathbf{F}$ & $\%$ & & & \multirow{5}{*}{0,785} \\
\hline \multicolumn{7}{|l|}{ Jenis Kelamin } & \\
\hline Laki-Laki & 5 & 55,6 & 4 & 44,4 & 9 & 100,0 & \\
\hline Perempuan & 9 & 50,0 & 9 & 50,0 & 18 & 100,0 & \\
\hline Total & 14 & 51,9 & 13 & 48,1 & 27 & 100,0 & \\
\hline
\end{tabular}




\begin{tabular}{|c|c|c|c|c|c|c|c|}
\hline $31-40$ & 1 & 33,3 & 2 & 66,7 & 3 & 100,0 & \multirow{5}{*}{0,321} \\
\hline $41-50$ & 4 & 80,0 & 1 & 20,0 & 5 & 100,0 & \\
\hline $51-60$ & 6 & 60,0 & 4 & 40,0 & 10 & 100,0 & \\
\hline $61-70$ & 3 & 33,3 & 6 & 66,7 & 9 & 100,0 & \\
\hline Total & 14 & 51,9 & 13 & 48,1 & 27 & 100,0 & \\
\hline \multicolumn{8}{|c|}{ Olahraga } \\
\hline Sering & 14 & 22,2 & 4 & 22,2 & 18 & 100,0 & \multirow{3}{*}{0,000} \\
\hline Jarang & 0 & 0,0 & 9 & 100,0 & 9 & 100,0 & \\
\hline Total & 14 & 51,9 & 13 & 48,1 & 27 & 100,0 & \\
\hline
\end{tabular}

Berdasarkan Tabel 4, jenis kelamin laki-laki lebih banyak dengan tekanan darah normal yaitu 5 orang $(55,6 \%)$. Sedangkan untuk jenis kelamin perempuan memiliki jumlah yang sama untuk tekanan darah normal maupun hipertensi yaitu masing-masing sebesar 9 orang $(50,0 \%)$.Untuk mengetahui hubungan antara jenis kelamin dengan hipertensi dilakukan tabulasi silang (analisis chi-square) dan secara statistik menunjukkan tidak terdapat hubungan antarajenis kelamin dengan hipertensi, dengan nilai $P=0,785 \quad(P \quad>0,05)$. Responden dengan usia 31-40 tahun dan 61-70 tahun lebih banyak yang terkena hipertensi yaitu masing-masing sebesar 2 orang $(66,7 \%)$ dan 6 orang

\section{PEMBAHASAN}

Hubungan Jenis Kelamin, Usia, dan Olahraga terhadap Kadar Kolesterol Total

Berdasarkan hasil penelitian yang telah dilakukan menunjukkan bahwa: untuk variabel kadar kolesteroltotal responden perempuan lebih banyak jika dibandingkan dengan responden lakilaki, yaitu sebesar 23 orang $(82,1 \%)$.Menurut penelitian sebelumnya, pada masa kanak-kanak, perempuan memiliki nilai kolesterol yang lebih tinggi jika dibandingkan dengan laki-laki(Pradana \& Pratama, 2018).

Kemudian berdasarkan usia, responden paling banyak berada pada kelompok usia 51-60 tahun yaitu sebesar 11 orang (39,3\%).Secara statistik menunjukkan tidak terdapat hubungan antarausia dengan kadar kolesterol total, dengan nilai $P=0,110$ ( $P$ $>0,05)$. Hal ini sejalan dengan penelitian (Yoentafara, 2017),
$(66,7 \%)$. Sedangkan untuk responden dengan usia 41-50 tahun dan 51-60 tahun lebih banyak dengan tekanan darah normal masing-masing sebanyak 4 orang $(80,0 \%)$ dan 6 orang $(60,0 \%)$. Secara statistik menunjukkan tidak terdapat hubungan antarausia dengan hipertensi, dengan nilai $P=0,321$ ( $P$ $>0,05)$. Responden yang sering olahraga lebih banyak dengan tekanan darah normal yaitu 14 orang $(22,2 \%)$ dan untuk responden yang jarang olahraga keseluruhan responden mengalami hipertensi yaitu 9 orang $(100,0 \%)$. Secara statistik menunjukkanterdapat hubungan antaraolahraga dengan hipertensi, dengan nilai $P=0,000(P<0,05)$.

hubungan variabel usia dengan kadar kolesterol total menunjukkan sebagian besar responden yang memiliki kadar kolesterol total tinggi adalah kelompok usia $\geq 45$ tahun (75\%). Bedasarkan hasil uji statistik diperoleh hasil uji chi-square dengan nilai $p=1(p>0,05)$ berarti tidak ada hubungan antara usia dengan kadar kolesterol total (Yoeantafara \& Martini, 2017).

Proses penuaan adalah suatu proses yang alamiah yang diikuti dengan adanya penurunan kondisi psikologis, fisik maupun sosial yang saling berinteraksi satu sama lain. Usia diatas 45 tahun adalah rentang usia yang berisiko untuk menderita hiperkolesterolemia(Yoeantafara \& Martini, 2017).Kadar kolesterol akan mengalami peningkatan secara bertahap seiring bertambahnya usia(Hermawati, N. Ayu Gustia, 2018).

Hasil uji statistik (analisis chisquare)menunjukkan terdapat hubungan antara olahraga dengan kadar kolesterol total, yaitu dengan nilai 
$P=0,000 \quad(P<0,05)$. Hal ini sesuai dengan penelitian sebelumnya(Berawi, 2016) di Lampung yaitu hasil uji statistik dengan uji t di dapatkan pvalue $=0,007(a=0,05)$, yang berarti bahwa ada hubungan yang signifikan antara olahraga senam jantung sehat terhadap penurunan kadar kolesterol total darah pada lansia(Berawi, Nisa, 2016). Penelitian (Pradana, 2018), juga menyatakan bahwa terdapat efek kerja senam jantung terhadap penurunan Kadar Kolesterol Total (Pradana \& Pratama, 2018).

Pada kegiatan olahraga dengan aktivitas aerobik yang dominan, metabolisme energi akan berjalan melalui pembakaran simpanan karbohidrat, lemak dan sebagian kecil $( \pm 5 \%)$ dari pemecahan simpanan protein yang terdapat di dalam tubuh untuk menghasilkan ATP (Pradana \& Pratama, 2018).

Hubungan Jenis Kelamin, Usia, dan Olahraga terhadap Hipertensi

Responden perempuan lebih banyak dibandingkan dengan responden lakilaki yaitu sebesar 18 orang $(66,7 \%)$.Berdasarkan analisis chisquare dan secara statistik menunjukkan tidak terdapat hubungan antarajenis kelamin dengan hipertensi, dengan nilai $P=0,785 \quad(P>0,05)$. Penelitian (Wahyuni\& Susilowati, 2018) menunjukkan hal yang sama yaitu responden perempuan sebanyak 31 responden (62\%) lebih banyak daripada responden laki-laki sebanyak 19 responden (38\%). Jenis kelamin lakilaki memiliki gaya hidup yang cenderung dapat menaikkan tekanan darah daripada perempuan. Sedangkan perempuan akan semakin tinggi resikonya mengalami hipertensi saat masuk usia menopause yaitu usia diatas 45 tahun(Wahyuni \& Susilowati, 2018; Anggriawan, 2015).

Berdasarkan hubungan usia terhadap hipertensi, responden dengan usia 31-40 tahun dan 61-70 tahun lebih banyak yang terkena hipertensi yaitu masing-masing sebesar 2 orang $(66,7 \%)$ dan 6 orang $(66,7 \%)$. Secara statistik menunjukkan tidak terdapat hubungan antarausia dengan hipertensi, dengan nilai $P=0,321 \quad(P>0,05)$. Semakin bertambahnya umur seseorang maka terjadi perubahan struktur pada pembuluh darah besar, sehingga pembuluh darah menjadi lebih sempit dan dinding pembuluh darah menjadi kaku, akibatnya adalah akan meningkatnya tekanan darah (hipertensi)(Wahyuni \& Susilowati, 2018).

Berdasarkan olahraga terhadap hipertensi, hasil penelitian menunjukkanterdapat hubungan antaraolahraga dengan hipertensi, dengan nilai $P=0,000(P<0,05)$. Hal ini sejalan dengan penelitian (Sumartiniet al, 2019), hasil uji statistik menunjukkan $\quad \rho=0,000 \quad(<a=0,05)$ sehingga dapat disimpulkan bahwa ada pengaruh senam hipertensi lansia terhadap tekanan darah lansia hipertensi (Sumartini etal, 2019).Penelitian(Putriastuti, 2016) di Puskesmas Kedurus Surbaya juga memperlihatkan hal yang sama yaitu hasil uji statistik dengan chi square didapatkan p-value $=0,000(a=0,05)$, yangberarti bahwa ada hubungan yang signifikan antara olahraga dengan kejadian hipertensi(Putriastuti, 2016).

Menurut Rai (2012), olahraga aerobik yang baik dapat menurunkan tekanan darah sistolik sebesar 4-5 $\mathrm{mmHg}$ dan tekanan diastolik sebesar 3$4 \mathrm{mmHg}$. Olahraga yang baik merujuk pada jenis, tata cara dan waktu pelaksanaan latihan (Rai, 2012).

\section{KESIMPULAN}

Berdasarkan penelitian yang telah dilakukan dapat disimpulkan tidak ada hubungan antara jenis kelamin dengan kadar kolesterol total dan hipertensi.Berdasarkan usia diperoleh tidak ada hubungan antara usia dengan kadar kolesterol totaldan hipertensi. Serta, berdasarkan olahraga diperoleh ada hubungan antara olahraga dengan kadar kolesterol totaldan hipertensi.

\section{SARAN}

Diharapkan hasil penelitian ini dapat dijadikan sebagai evidence based untuk penelitian selanjutnya dan 
tambahan informasi untuk mengembangkan penelitian lebih lanjut tentang manfaat lain terkait olahraga yang berpengaruh terhadap perubahan kadar kolesterol total dan hipertensi.

\section{DAFTAR PUSTAKA}

Anggriawan, N. (2015). Peran Fisiologi Olahraga Dalam Menunjang Prestasi. Jurnal Olahraga Prestasi, 11(2), 114694. https://doi.org/10.21831/jorpres.v $11 \mathrm{i} 2.5724$

Arsana, P. M., Rosandi, R., Manaf, A., Budhiarta, A., \& Permana, H. (2019). Pedoman Pengelolaan Dislipidemi di Indonesia 2019.

Ayu, A. M., Mutalazimah, M., \& Herawati, I. (2017). Hubungan Frekuensi Senam Aerobik dan Asupan Kolesterol Terhadap Kadar Kolesterol Darah Wanita Usia Subur di Pusat Kebugaran Syariah Agung Fitnes Makamhaji. Jurnal Kesehatan, 10(2), 74. https://doi.org/10.23917/jurkes.v1 $0 \mathrm{i} 2.5536$

Badan Penelitian dan Pengembangan Kesehatan Kementrian Kesehatan RI. (2014). Laporan Nasional Riset Kesehatan Dasar (RISKESDAS) 2013.

Benjamin EJ, Blaha MJ, C. S. et al. (2017). Heart Disease and Stroke Statistic 2017 Update: A Report From the American Heart Association.

Berawi, Nisa, K. (2016). Penurunan Kadar Kolesterol Total Darah sebagai Resiko Dislipidemia pada Lansia yang Mengikuti Senam Jantung Sehat. JK Unila, 1.

Hafid, M. A. (2015). Hubungan Gaya Hidup Dengan Prevalensi Hipertensi Di Puskesmas Kassi-Kassi Kabupaten Bantaeng Tahun 2014. JF FIK UINAM, 3(1), 27-36.

Harimba, A. (2017). Pengaruh Latihan Beban Terhadap Kadar Kolesterol Total Darah. Fakultas Kedokteran Universitas Hasanudin.

Hermawati, N. Ayu Gustia, Y. D. (2018). Pengaruh Aktivitas Olah Raga Terhadap Kadar Kolesterol Total Di Poli Klinik Jantung. Jurnal
Kesehatan Saintika Meditory Jurnal Kesehatan Saintika Meditory, 2(August), 79-88. Retrieved from http://jurnal.syedzasaintika.ac.id/in dex.php/meditory/article/view/244

Kemenkes RI. (2016). Profil Penyakit Tidak Menular Tahun 2016. In Journal of Chemical Information and Modeling (Vol. 53).

Kementerian Kesehatan RI. (2018). Situasi Kesehatan Jantung; Mari Menuju Masa Muda Sehat, Hari Tua Nikmat Tanpa PTM dengan Perilaku Cerdik. 8.

Lin, C., Chang, Y., Chien, S., \& Lin, Y. (2018). Epidemiology of Dyslipidemia in Asia Pacific Region. International Journal Gerontology, $12,2-6$.

Magdalena. (2015). Hubungan Asupan Serat, Kolesterol, Natrium Dan Olahraga Dengan Kadar Kolesterol Dan Hipertensi Pada Lansia. Medical Laboratory Technologist, 92(2), 587-591.

Munawarah, S. (2017). Pengaruh Jalan Santai Terhadap Tekanan Darah Pada Penderita Hipertensi Warga RW 005 Pisangan Barat Ciputat. 120.

Naim, M. R., Sulastri, S., \& Hadi, S. (2019). Gambaran Hasil Pemeriksaan Kadar Kolesterol Pada Penderita Hipertensi Di Rsud Syekh Yusuf Kabupaten Gowa. Jurnal Media Laboran, 9(2).

PERKI. (2019). World Heart Day PERKI.

Pradana, V. O., \& Pratama, R. (2018). Efek Kerja Senam Jantung Sehat terhadap Kadar Kolesterol Total Klub Jantung Sehat Mitra Pegangsaan. Jurnal Terapan IImu Keolahragaan, 3(1), 12. https://doi.org/10.17509/jtikor.v3i 1.10395

Putriastuti, L. (2016). Analisis Hubungan Antara Kebiasaan Olahraga Dengan Kejadian Hipertensi Pada Pasien Usia 45 Tahun Keatas. Jurnal Berkala Epidemiologi, 4(August 2016), 225-236. https://doi.org/10.20473/jbe.v4i2. 2016.225

Rai, A. (2012). 101 Fitness di Usia 40+. 
Jakarta: Libri.

Sumartini, N. P., Zulkifli, Z., \& Adhitya, M. A. P. (2019). Pengaruh Senam Hipertensi Lansia Terhadap Tekanan Darah Lansia Dengan Hipertensi Di Wilayah Kerja Puskesmas Cakranegara Kelurahan Turida Tahun 2019. Jurnal Keperawatan Terpadu (Integrated Nursing Journal), 1(2), 47. https://doi.org/10.32807/jkt.v1i2.3 7

Wahyuni, W., \& Susilowati, T. (2018). Pola Makan Dan Jenis Kelamin Dan Hubungan Pengetahuan Terhadap Kejadian Hipertensi Di Kalurahan Sambung Macan Sragen. Gaster I
Jurnal Ilmu Kesehatan, 16(1), 73. https://doi.org/10.30787/gaster.v1 $6 \mathrm{i} 1.243$

Wahyuni, W. T. (2014). Tingkat Pengetahuan Mahasiswa Fakultas IImu Kesehatan Universitas Muhammadiyah Palangkaraya Tentang Penyakit Kolesterol. 1-89.

WHO. (2014). World Health Organization 2014: A Wealth of Information on Global Public Health.

Yoeantafara, A., \& Martini, S. (2017). Pengaruh Pola Makan Terhadap Kadar Kolesterol Total. Media Kesehatan Masyarakat Indonesia, 13(4),

304. 